\title{
Impact of White Pine Blister Rust on Resistant Cultivated Ribes and Neighboring Eastern White Pine in New Hampshire
}

Isabel A. Munck, Northeastern Area State and Private Forestry, United States Department of Agriculture Forest Service, Durham, NH 03824; Philippe Tanguay, Canadian Forest Service, Laurentian Forestry Centre, Sainte-Foy, QC, G1V 4C7, Canada; Jennifer Weimer, New Hampshire Department of Resources and Economic Development, New Hampshire Division of Forests and Lands, Concord 03302; and Sara M. Villani and Kerik D. Cox, Department of Plant Pathology and Plant-Microbe Biology, New York State Agricultural Experiment Station, Cornell University, Geneva 14456

\begin{abstract}
Munck, I. A., Tanguay, P., Weimer, J., Villani, S. M., and Cox, K. D. 2015. Impact of white pine blister rust on resistant cultivated Ribes and neighboring eastern white pine in New Hampshire. Plant Dis. 99:1374-1382.

To determine the impact of white pine blister rust (WPBR) following the recent breakdown of the $\mathrm{Cr}$ resistance dominant gene in cultivated Ribes spp., 255 plants of 19 Ribes cultivars and 445 neighboring eastern white pine (Pinus strobus) from 42 sites across New Hampshire were evaluated. Of the 19 Ribes cultivars evaluated, 15 were WPBR resistant, and 4 of these were labeled as black currant (Ribes nigrum) with the $\mathrm{Cr}$ gene (Cr Ribes cultivars). Incidence of WPBR ranged from 0 to $88 \%$ for WPBR-resistant Ribes cultivars. Mean WPBR severity was 14 and $<6 \%$ of leaf area for $\mathrm{Cr}$ Ribes and partially resistant cultivars, respectively. The presence of Cronartium ribicola was confirmed on 17 of the 19 Ribes cultivars screened with polymerase chain reaction

analysis and DNA sequencing. Reference accessions of $\mathrm{Cr}$ Ribes cultivars from the Canadian Clonal Genebank were successfully infected with $C$. ribicola inoculum collected in New Hampshire from $\mathrm{Cr}$ Ribes cultivars and $P$. strobus, confirming that the $\mathrm{vCr}$ race of $C$. ribicola that has overcome the $\mathrm{Cr}$ resistance dominant gene in cultivated Ribes spp. is present in New Hampshire. The probability of finding pine trees with WPBR was greater for trees neighboring infected $\mathrm{Cr}$ Ribes cultivars (0.18) than trees neighboring WPBR-free Ribes cultivars (0.02). Results from this study suggest that the breakdown of $\mathrm{Cr}$-based resistance in Ribes spp. poses a threat to the white pine resource and to cultivated Ribes production.
\end{abstract}

The causal agent of white pine blister rust (WPBR), Cronartium ribicola J. C. Fisch. 1872, has been a threat to both forest resources and agricultural commodities since its introduction to North America in the early 1900s (Ostry et al. 2010; Posey and Ford 1924; Stewart 1906). C. ribicola has a complicated lifecycle, alternating between five-needle pine and telial hosts such as currant or gooseberry in the genus Ribes (Spaulding 1922a). In the spring, aeciospores produced in pine infect alternate Ribes hosts (Geils et al. 2010; Spaulding 1911). Aeciospores are thick walled and pigmented (Kasanen 1997), and are capable of traveling in wind currents for thousands of kilometers (Mielke 1943). Urediniospores, produced on the underside of Ribes leaves, mainly from late May to early September, locally infect other Ribes plants, thus intensifying the spread of the pathogen among Ribes hosts (Geils et al. 2010). Before leaf fall, telia differentiate, and meiosis in teliospores produces basidiospores that infect white pine. Basidiospores are relatively fragile and cannot travel long distances (Zambino 2010). Except in the case of early defoliation, where WPBR has been shown to reduce fruit yield (Pedersen 1998, 2008), the disease is generally not considered a serious economic problem to the Ribes industry. However, plant regulatory measures taken to protect the white pine resource could influence Ribes cultivation. In contrast, infection by C. ribicola in white pine is devastating to pine production and may ultimately lead to tree mortality (Luffman 2000). Indeed infection of pine trees can result in girdling cankers and tree death (Geils et al. 2010; Kearns and Jacobi 2007; Lachmund 1933; Slipp 1953). Young trees die more rapidly because it takes less time for the pathogen to completely girdle their main stems (Geils et al. 2010) but all size classes are killed by WPBR (Martin 1937).

Corresponding author: I. Munck; E-mail: imunck@fs.fed.us

Accepted for publication 19 February 2015.

http://dx.doi.org/10.1094/PDIS-12-14-1338-RE

This article is in the public domain and not copyrightable. It may be freely reprinted with customary crediting of the source. The American Phytopathological Society, 2015.
Eastern white pine (Pinus strobus L.) is one of the most ecologically, historically, and economically important tree species in eastern North America. White pine provides unique terrestrial habitat elements for wildlife that other large conifer species cannot duplicate (Yamasaki 2003). White pine composes the greatest portion of the growing stock (volume of all living trees in a given area) in Massachusetts $(24 \%)$, followed by New Hampshire $(21 \%)$ and Maine (10\%) (Widmann and McWilliams 2003). Eastern white pine is also valued in the ornamental and nursery trade (Bergdahl and Teilon 2000). In 2013, the contribution of forest-based manufacturing and forest-related recreation and tourism to the economy in Maine, New Hampshire, Vermont, and New York was over \$33 billion (NESFA 2013). The white and red pine forest type covers approximately 1.25 million ha $(10 \%)$ of New England's timberland and contributes to the aesthetics sought after by tourists and recreationists.

WPBR was introduced to the United States from Europe more than a century ago via imported plant material (Maloy 1997; Posey and Ford 1924; Spaulding 1922a). The absence of coevolution between the invasive pathogen and its aecial hosts, in addition to the establishment of native white pine and Ribes spp. throughout the eastern and western United States, provided a favorable environment for WPBR epidemics (Dalton et al. 2010; Smith et al. 2006). Early management of the disease focused primarily on elimination of its alternate host via widespread Ribes eradication. To protect the white pine resource, Ribes spp. were quarantined and destroyed throughout the United States from 1917 to 1967 by the Blister Rust Control Program (Benedict 1981; Maloy 1997). Removing the alternate host has long been used to control WPBR because C. ribicola must cycle through Ribes spp. in order to infect white pine, and delicate basidiospores have a limited infective range (Zambino 2010). These efforts continued for more than 40 years but they were abandoned for a variety of reasons, including increased costs, labor shortages, interagency squabbling, and difficulty in removing certain native Ribes spp., especially in the West, where pine stands grew in inaccessible and rugged terrain (Maloy 1997). More recently, fungicide management to control WPBR on susceptible cultivated Ribes spp. has demonstrated effectiveness in reducing 
but not eliminating initial urediniospore inoculum in small-scaled research Ribes operations (Cox et al. 2008).

Interest in Ribes cultivation in the United States increased in the late 1990s, sparking an inquiry by foresters, pathologists, horticulturists, and regulators to determine the threat of Ribes spp. to pine (McKay 2000). The results of the inquiry were varied, and state regulatory agencies differed in their wish to change Ribes regulations. Several knowledge gaps arose, including the need to assess incidence of WPBR on pine and the longevity of WPBR resistance in Ribes cultivars (McKay 2000). To help regulators make informed decisions and quantify whether WPBR incidence on eastern white pine had changed since the 1900 s, a statewide survey was conducted in New Hampshire during 1998 (Lombard and Bofinger 1999). Survey results indicated that WPBR incidence had decreased from 20 to $80 \%$, reported in the early to mid- 1900 s, to a range of 0.3 to $7.2 \%$, depending on the region (Lombard and Bofinger 1999). Field trials conducted during 1995 and 1996 at the United States Department of Agriculture-Agricultural Research Service (USDA-ARS) National Clonal Germplasm Repository in Oregon identified several WPBRresistant Ribes cultivars (Hummer 1997). As a result of these findings, New Hampshire changed its regulations in 2002 to allow planting of resistant Ribes cultivars. By 2009, 19 WPBR-resistant Ribes cultivars were available for planting, including 4 European black currant cultivars with the $\mathrm{Cr}$ dominant resistance gene from Ribes ussuriense $(\mathrm{Cr}$ Ribes cultivars) (Hummer and Finn 1999). None of the cultivars with the $\mathrm{Cr}$ dominant resistance gene or partial resistance approved for planting in New Hampshire produced uredia after exposure to natural infection in Oregon field trials (Hummer 1997; Hummer and Finn 1999). Additionally, most cultivars did not produce uredia after artificial inoculation with $C$. ribicola urediniospores (Hummer and Picton 2002).

In 2011, WPBR incidence was reported on a Cr Ribes cultivar, R. nigrum 'Titania', in Connecticut (Frederick et al. 2011). A preliminary survey in 2012 indicated the presence of WPBR on 'Titania' and other cultivars planted in New Hampshire. These findings caused concern to regulators and forest health managers in New Hampshire, who decided that a more complete assessment of Ribes plantings and the impact on local white pine was needed. The objectives of this study were to (i) evaluate WPBR incidence and severity on WPBRresistant Ribes cultivars, (ii) determine WPBR incidence and severity on neighboring eastern white pine and wild Ribes spp., (iii) verify presence of $C$. ribicola with molecular diagnostic techniques, and (iv) challenge Ribes spp. with $C r$-based resistance of reliable provenance from the Canadian Clonal Genebank with New Hampshire C. ribicola samples.

\section{Materials and Methods}

Site selection. A permit specifying location, cultivar, and number of plants must be submitted to the State's Division of Forests and Lands (NHDFL) to plant Ribes spp. in New Hampshire. In total, 43 sites out of 109 permit holders were visited from 31 July to 4 September 2013, when C. ribicola uredia or telia were visible on the lower leaf surface of Ribes plants and before leaf drop. Thirty-eight sites were randomly selected to assess the incidence and severity of WPBR. An additional five sites were surveyed to obtain descriptive data for Ribes cultivars rarely planted in New Hampshire.

Ribes sampling in New Hampshire. Field surveys and collections were conducted by the U.S. Forest Service (USFS) and NHDFL. At each site, disease incidence and severity were assessed for up to five plants per cultivar. The disease severity rating scale developed for grapevine rust (Angelotti et al. 2008) was used to estimate percentage of diseased leaf area on the lower side of leaves for 18 leaves per plant: 3 leaves from the top, middle, and base of each of two randomly selected canes. Plants were considered positive for WPBR if any of the 18 leaves inspected to assess disease severity or any other leaves had $C$. ribicola signs on their lower surfaces. The same methods were used to assess disease incidence and severity for wild or naturalized Ribes spp. found in the vicinity of cultivated Ribes plants or neighboring white pine trees. At each site, infected leaves from each cultivar were placed in labeled paper envelopes that were pressed in a plant press until they could be mailed to Cornell for polymerase chain reaction (PCR) analyses. Infected leaves from Cr Ribes cultivars 'Coronet', 'Consort', 'Crusader', and 'Titania' were collected in the same manner and mailed to Canada for infection assays.

Confirmation of pathogen identity. Pathogen diagnoses were conducted by Cornell University. At each site, composite samples comprising 10 to 33 Ribes leaves with putative WPBR pustules were collected from each cultivar and stored at $7{ }^{\circ} \mathrm{C}$ for genetic confirmation of $C$. ribicola. Prior to amplification of rust DNA using PCR, the rust uredinia, urediniospores, or telia were isolated from leaf tissue by repeatedly pressing a 1-by-1-cm square of single-sided, matt finish, Scotch Magic Tape (3M, St. Paul, MN) lightly to the surface of currant leaves with evidence of rust infection. The tape pieces were subsequently placed in individual $2.0-\mathrm{ml}$ microcentrifuge tubes containing a sterile bead and were dipped in liquid nitrogen for $30 \mathrm{~s}$. Fungal tissue was mechanically disrupted using a TissueLyser System (Qiagen, Germantown, MD), and DNA was extracted using a DNeasy Plant Mini Kit (Qiagen) according to the manufacturer's instructions. To confirm the identity of $C$. ribicola, primers $15337 \mathrm{AG}$ (5'-TTT GTG GAC TTG CAG GTT TG-3') and 15337AF (5'-CGG ACC AAC TTT CCT AGT CG-3') for a $C$. ribicola gene encoding a protein with homology to phenol 2-monooxygenase were used to generate an approximately 660-bp fragment from genomic DNA (Brar 2012). PCR reactions were made in $25-\mu 1$ reaction volumes and contained $1 \times$ PCR buffer, $0.4 \mu \mathrm{M}$ each primer, $2.5 \mathrm{mM} \mathrm{MgCl}_{2}$, $200 \mu \mathrm{M}$ each dNTP, $0.625 \mathrm{U}$ of GoTaq Flexi DNA polymerase (Promega Corporation, Madison, WI), and $5 \mathrm{ng}$ of extracted DNA. Amplifications were performed using an iCycler thermal cycler (Bio-Rad Laboratories Inc., Hercules, CA) with the following cycling protocol: $3 \mathrm{~min}$ at $94^{\circ} \mathrm{C} ; 30$ cycles of $30 \mathrm{~s}$ at $94^{\circ} \mathrm{C}, 30 \mathrm{~s}$ at $50^{\circ} \mathrm{C}$, and $1 \mathrm{~min}$ at $72^{\circ} \mathrm{C}$; followed by a final extension step of $10 \mathrm{~min}$ at $72{ }^{\circ} \mathrm{C}$. PCR products were separated on a $2.0 \%$ agarose gel (Bio-Rad Laboratories Inc.) stained with ethidium bromide in $1 \times$ Tris-acetate-EDTA buffer at $100 \mathrm{~V}$ for $1 \mathrm{~h}$. Photographs of the gel were taken on a KODAK Gel Logic 200 Imaging System (Eastman Kodak Company, Rochester, NY). A previously confirmed isolate of $C$. ribicola was included each time PCR was conducted in order to detect false-negative results. For a subsample of isolates, additional genetic confirmation was accomplished by sequencing the two internal transcribed spacer (ITS) regions and the 5.8S gene in the nuclear ribosomal repeat using primers ITS1-F and ITS-4, as described previously (Gardes and Bruns 1993).

White pine sampling in New Hampshire. Field surveys and collections were conducted by USFS and NHDFL. During July and September 2013, the 12 closest pine trees within $300 \mathrm{~m}$ of cultivated Ribes spp. ( 3 trees in each of the four cardinal directions, if available) were examined for WPBR signs and symptoms at each site. WPBR symptoms included aecial scars, flagging, spindleshaped cankers, bark discoloration, resinosis, and crown discoloration. A distinction was made between pine with aecial scaring and pine with other symptoms. Distance and cardinal direction from cultivated Ribes spp. were determined with the aid of a GPS receiver (GPSmap 60CSx; Garmin International Inc., Olathe, KS) and a compass. Stem diameter at breast height ( $\mathrm{dbh} ; 1.3 \mathrm{~m}$ above the ground) was recorded for each pine.

During April and May 2014, sites with pine trees containing aecial scars in sites with plants labeled as $\mathrm{Cr}$ Ribes cultivars infected by $C$. ribicola in August 2013 were revisited to collect aeciospores. At each site, pine trees with aecia within $300 \mathrm{~m}$ of $\mathrm{Cr}$ Ribes cultivars were sampled. Aeciospores were collected from single unruptured aecia by carefully ripping the peridium with a toothpick and inserting the spores into an Eppendorf tube. Up to 10 aecia were sampled per canker, working from the bottom of the canker upward to avoid contamination. Spores from one aecium represented a sample. Samples from up to three cankers per tree were collected. Samples were brought to the laboratory and kept at $4{ }^{\circ} \mathrm{C}$ until they were shipped to Canada for infection assays within 3 days of their collection.

Plant material for infection assays. Infection assays were conducted by the Canadian Forest Service. The susceptible black currant 
control R. nigrum 'Ben Lomond' was bought at a nursery in Quebec City. Cuttings from the black currant accessions with the $\mathrm{Cr}$ gene ('Consort', 'Crusader', and 'Coronet', with accession numbers CN102541, CN102560, and 102561, respectively) were kindly provided by the Canadian Clonal Genebank (Agriculture and Agri-Food Canada) located at the Harrow Research Station (Ontario, Canada). Dormant cuttings were stuck in Rootcubes (Oasis Grower Solutions) and rooted using a hydroponic flood table system (American Hydroponics). Rooted cuttings were transferred into a mix of peat moss, vermiculite, and turface (ratio 4:2:1) and grown under greenhouse conditions with a photoperiod of $16 \mathrm{~h} /$ day and $8 \mathrm{~h} /$ night at 24 and $20^{\circ} \mathrm{C}$, respectively.

Infection assay of $\boldsymbol{C}$. ribicola on detached Ribes leaves. Rust from New Hampshire field collections was pathotyped on reference accessions of $\mathrm{Cr}$ Ribes cultivars 'Consort', 'Coronet', and 'Crusader' from the Canadian Clonal Genebank. Presence of the $\mathrm{vCr}$ race of C. ribicola that has defeated the $\mathrm{Cr}$ resistance dominant gene in cultivated Ribes spp. was determined by using controlled leaf inoculations of reference accessions of $\mathrm{Cr}$ Ribes cultivars with urediniospores or aeciospores collected from infected leaves of plants labeled as $\mathrm{Cr}$ Ribes cultivars in New Hampshire or from neighboring white pine cankers, respectively. Monouredinal C. ribicola strains were propagated on detached leaves from the susceptible black currant control 'Ben Lomond' (without the $\mathrm{Cr}$ gene) and reference accessions $\mathrm{Cr}$ Ribes cultivars from the Canadian Clonal Genebank (with the $\mathrm{Cr}$ gene). Ribes leaves from leaf plastochrony index 6 to 10 were removed from the plant, and pieces from each susceptible and $\mathrm{Cr}$ Ribes cultivar were placed side by side onto a wet paper towel inside petri dishes. Sterile cotton swabs were used to inoculate leaf abaxial surfaces with the urediniospores or aeciospores collected in New Hampshire from infected leaves of plants labeled as $\mathrm{Cr}$ Ribes cultivars or pine cankers, respectively. Petri dishes were incubated at $19^{\circ} \mathrm{C}$ under a 16 -h photoperiod and $80 \%$ relative humidity. Bulk aeciospores preserved at $-80^{\circ} \mathrm{C}$ and collected in 2008 from cankers in a white pine plantation in SaintIsidore (Quebec, Canada) were used for negative controls. Leaf pieces were inoculated within 15 and 4 days of uredial and aecial sample collection, respectively. Pathogen growth was assessed 4 weeks postinoculation.

Statistical analyses. Only data from randomly selected sites and state-approved WPBR-resistant Ribes cultivars were used for analyses. Ribes plants were grouped by species because of the lack of repetition in each cultivar. A distinction was made between Cr Ribes cultivars ('Coronet', 'Consort', 'Crusader', and 'Titania') and 'Willoughby', a cultivar of unknown background selection of $R$. nigrum. To determine the effect of Ribes sp. on the incidence of infected Ribes plants, data were analyzed using a generalized linear mixed model (PROC GLIMMIX) in SAS (v. 9.3, 2011; SAS Institute Inc., Cary, NC). "Species" was a fixed effect, "site" was a random factor, and the binomial distribution with the logit link function for the response variable "proportion of plants with WPBR" was used. To establish the effect of Ribes sp. on WPBR severity on Ribes plants, data were analyzed using a linear mixed model (PROC GLIMMIX). "Species" was a fixed effect, "site" was a random factor, and the response variable was "mean percentage diseased leaf area per infected plant".

To explore the effects of variables associated with disease development on WPBR incidence of white pine, data were analyzed using a generalized linear model (PROC GLIMMIX) specifying binomial distribution and the logit link function for the response variables "proportion of pine with aecial scars" or "proportion of pine with aecial scars OR other symptoms". The response variable "proportion of pine with aecial scars" represents a more conservative estimate of WPBR incidence. Analyses were conducted separately for each of these two response variables. The effects of each of the following variables were individually tested: presence of infected Ribes spp. with and without $\mathrm{Cr}$ gene, tree size, distance within $300 \mathrm{~m}$ from Ribes plants, and cardinal direction from Ribes plants. Data from 26 sites with infected Ribes spp. only were used for analyses to determine the effect of distance and cardinal direction from infected Ribes plants on incidence of infected pine. For all models, when main effects were significant $(\alpha=0.05)$, a Tukey-Kramer test was used to identify differences among means.

\section{Results}

The impact of WPBR on 255 plants of 19 Ribes cultivars and 445 neighboring white pine trees from 43 sites was evaluated. Only three sites were managed for commercial Ribes production and the remaining locations were private gardens. The mean number of Ribes plants grown by commercial growers and private homeowners was 115 and 5, respectively. Most sites (76\%) had Ribes cultivars infected by C. ribicola (Fig. 1). All but two sites had pine trees neighboring cultivated Ribes plants. Symptomatic pine trees were observed at most sites $(63 \%)$ but fewer sites $(37 \%)$ had trees with aecial scars.

WPBR incidence and severity in Ribes spp. surveyed in New Hampshire. WPBR incidence and severity data were obtained for five species and a hybrid for a total of 19 cultivars, of which 15 were on present or previous state-approved lists (Table 1). North American Ribes spp. (R. oxyacanthoides L. and $R$. odoratum $\mathrm{H}$. Wendl.), European Ribes spp. (R. nigrum, $R$. rubrum L., and $R$. uva-crispa), and a currant $\times$ gooseberry hybrid (Ribes $\times$ nidigrolaria Bauer) were represented in the field in New Hampshire. In addition, incidence and severity data were collected for the following four cultivars not approved for planting in the state of New Hampshire: 'Red Lake', 'Blanka', 'Invicta', and 'Pixwell'. 'Titania' was the most frequently planted cultivar (Table 1).

Naturalized and wild Ribes spp. were found in only two sites. One location had three naturalized $R$. rubrum plants growing in the woods next to the cultivated Ribes sp. Two of these three plants were infected by $C$. ribicola and the mean percent diseased leaf area for these plants was $0.1 \%$. Another location had R. hirtellum Michx. growing on an old stone wall surrounding the property. This plant was infected and its mean percent diseased leaf area was $2 \%$. Disease severity of the wild and naturalized Ribes spp. was less than the disease severity of $\mathrm{Cr}$ Ribes cultivars 'Consort', 'Coronet', and 'Titania' and comparable with disease severity of other WPBR-resistant cultivars (Table 1).

Data from the 38 randomly selected sites only was used for comparisons of WPBR incidence and severity among Ribes spp. For incidence and severity analyses, observations from 220 and 103 plants, respectively were used. Except for Cr Ribes 'Crusader', which was not infected in the field, incidence of WPBR on other $\mathrm{Cr}$ Ribes cultivars ranged from 19 to $60 \%$ by cultivar, suggesting that these plants are either no longer resistant or possibly mislabeled (Table 1). Incidence of WPBR exceeded 50\% for most cultivars (10 of 15).

Ribes spp. differed in their susceptibility to WPBR. The main effect of Ribes spp. on WPBR incidence $(P=0.0024)$ and severity $(P<$ 0.0001 ) was statistically significant. Plants in the species $R$. oxyancanthoides, 'Jahns Prairie' gooseberry, were most likely to be diseased (predicted probability of disease $=0.88$; Fig. 2). In contrast, $R$. rubrum cultivars, red and white currants, were least likely to be diseased (predicted probability $=0.25$ ). In comparison, a third of $\mathrm{Cr} R i$ bes cultivars were predicted to be diseased. Cr Ribes cultivars exhibited the greatest percentage of diseased leaf area (15\%) compared with other Ribes spp. (0.1 to 6\%; Fig. 3). R. rubrum cultivars had the lowest percentage of diseased leaf area $(0.1 \%)$.

Confirmation of pathogen identity. Amplification of fungal DNA with primers $15337 \mathrm{AF}$ and $15337 \mathrm{AR}$ and sequencing of the ribosomal DNA ITS1, 5.8S, and ITS2 regions confirmed the presence of $C$. ribicola in all counties in New Hampshire and Ribes cultivars sampled in this study (Fig. 1; Table 1). With the exception of the Cr Ribes 'Crusader' and white currant '1301', samples from all other cultivars allowed in New Hampshire were PCR positive for $C$. ribicola, including $\mathrm{Cr}$ Ribes 'Consort', 'Coronet', and 'Titania' (Table 1).

Infection assay of $\boldsymbol{C}$. ribicola on detached Ribes leaves. From the last week of July to the first week of September 2013, 15 different plants labeled as Cr Ribes cultivars showing signs of WPBR were collected from 12 different sites within $113 \mathrm{~km}$ of each other in southern New Hampshire. Urediniospores from 6 of the $15 \mathrm{Cr}$ Ribes samples collected in New Hampshire from six different sites, all from plants labeled 'Titania', successfully infected detached leaves of reference accessions of Cr Ribes cultivars from the Canadian Clonal Genebank (Table 2). Uredia appeared and developed at the same 
speed on Cr Ribes cultivars and on the susceptible black currant control 'Ben Lomond' (without the $\mathrm{Cr}$ gene). During April and May 2014, aeciospores from 328 monoaecia were collected from 45 pine cankers in 10 different sites where infected pine trees were growing next to plants labeled as Cr Ribes cultivars with WPBR in August 2013. Aeciospores from 36 aecia from six cankers from a total of five pines in two locations $32 \mathrm{~km}$ from each other in New Hampshire successfully infected detached leaves of reference accessions of $\mathrm{Cr}$ Ribes cultivars from the Canadian Clonal Genebank (Table 3). Lack of infection for most of the aeciospores collected can most likely be attributed to nonviability at time of inoculation because these aeciospores also failed to infect leaves from the susceptible 'Ben Lomond' control. Bulk aeciospores collected in 2008 from cankers in a white pine plantation in Saint-Isidore (Quebec, Canada) used for negative

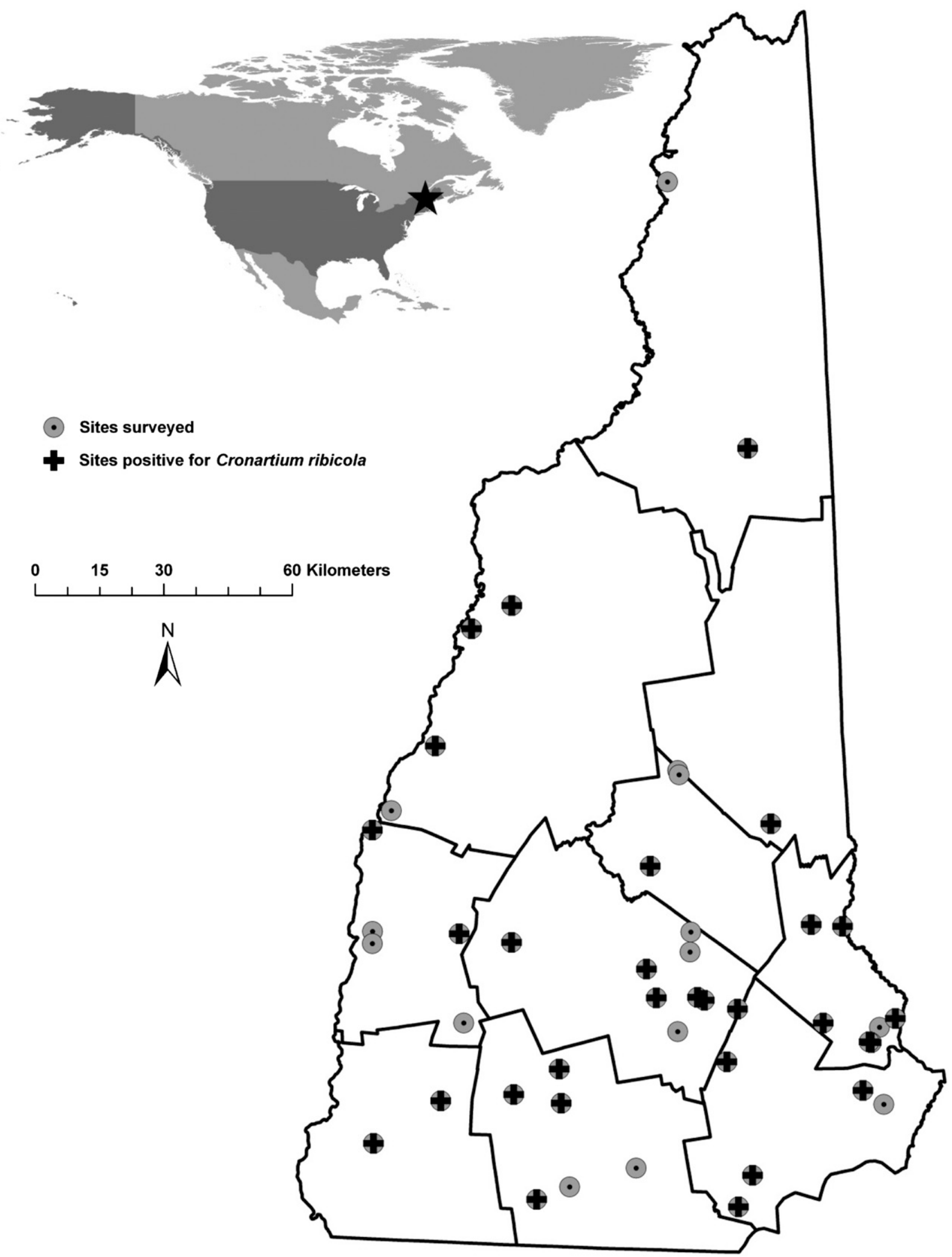

Fig. 1. Distribution of sites surveyed in New Hampshire to determine the impact of white pine blister rust on cultivated Ribes plants and neighboring white pine trees. Sites positive for Cronartium ribicola had infected cultivated Ribes spp. The identity of the pathogen was confirmed with molecular diagnostic techniques. 
controls successfully infected 'Ben Lomond' leaves but were avirulent on leaves from black currants with the $C r$ gene. These results show that the vCr race of $C$. ribicola that has overcome the $\mathrm{Cr}$ resistance dominant gene in cultivated Ribes spp. is present in both cultivated Ribes plants and white pine in New Hampshire.

WPBR incidence in white pine. Of the 385 pines from the 38 randomly selected sites, 37 pines had aecial scars and 74 had aecial scars or other WPBR symptoms such as resinosis, spindle-shaped cankers, flagging, or bark discoloration. Presence of infected Ribes plants influenced incidence of WPBR on white pine $(P<0.01)$. White pine trees with WPBR were found more frequently next to $\mathrm{Cr}$ Ribes cultivars infected with WPBR (probability $=0.18$ ) than next to other WPBRresistant Ribes cultivars infected with WPBR (probability $=0.09$ ) or next to Ribes without WPBR (probability $=0.02$ ) (Fig. 4). Distance within $300 \mathrm{~m}$ from infected Ribes plants also had a significant effect on WPBR incidence in pine, but only when pine trees with aecial scars were included in the analyses $(P=0.05)$. Pine trees within the first $60 \mathrm{~m}$ of infected Ribes spp. were more likely to be infected than trees further away (Fig. 5). The same trend was observed for pine trees with aecial scars or other WPBR symptoms but the main effect of distance $(P=0.09)$ was not significant at $\alpha=0.05$ for pine trees with other WPBR symptoms. The effect of cardinal direction downwind from infected Ribes plants on incidence of infected pine was not significant at $\alpha=0.05$ but was significant at $\alpha=0.1$ ( $P=0.06$ for pine trees with aecia and $P=0.08$ for trees with aecia or other WPBR symptoms). Consistent with prevailing wind directions in New England, it was more likely to find pines with aecia east (probability $=0.15$ ) or west (probability $=0.19)$ than north (probability $=0.02$ ) of infected Ribes plants. Similarly, it was more likely to find pines with aecia or other WPBR symptoms east (probability $=0.24$ ) or west (probability $=0.31$ ) than north (probability $=0.11$ ) of infected Ribes plants. Finally, tree size had a significant effect on WPBR incidence on white pine $(P=$ $0.0001)$. Seedlings $(\mathrm{dbh}<2.5 \mathrm{~cm})$ were at least five times more likely to be infected than saw timber-size trees $(\mathrm{dbh}>23 \mathrm{~cm}$ ) (Fig. 6).

\section{Discussion}

Cronartium ribicola is one of the most damaging invasive forest pathogens introduced to North America (Aukema et al. 2010; Liebhold et al. 1995, 2012). In the Northeast, the ubiquitous presence of a very susceptible exotic plant, $R$. nigrum, intensified damage caused by WPBR to native eastern white pine (Benedict 1981). European black currant, consequently, has been regulated since the early 1900s. In the early 2000 s, when state regulators were considering relaxing Ribes restrictions to allow planting of WPBR-resistant Ribes cultivars, Bergdahl and Teilon (2000) cautioned that the resistance might change over time. As predicted, the breakdown of the $\mathrm{Cr}$ resistance

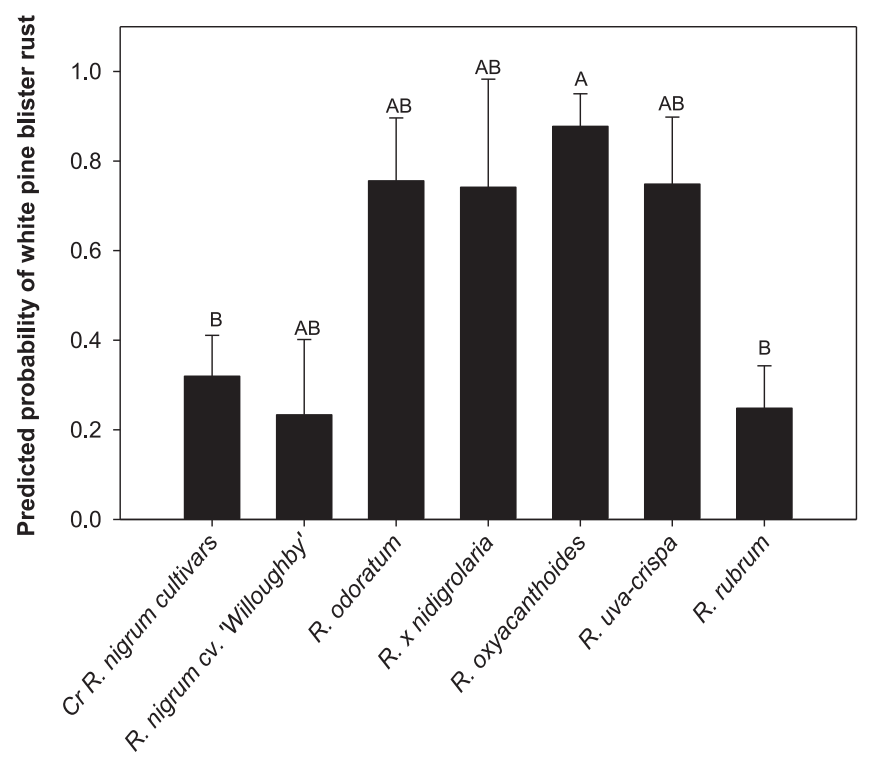

Ribes species

Fig. 2. Comparison of white pine blister rust incidence among cultivated Ribes spp. in New Hampshire. European black currant cultivars 'Titania', 'Consort', 'Coronet', and 'Crusader' are defined as $\mathrm{Cr}$ Ribes cultivars. Error bars represent standard errors. Values with the same letter are not statistically different $(\alpha=0.05)$.

Table 1. Descriptive data for currant and gooseberry plants in the genus Ribes sampled in New Hampshire to determine white pine blister rust (WPBR) disease incidence and severity of each cultivar

\begin{tabular}{|c|c|c|c|c|c|c|c|c|}
\hline Type of fruit & Ribes spp. & Cultivar & $\begin{array}{c}\text { WPBR } \\
\text { incidence }^{a}\end{array}$ & $\begin{array}{l}\text { Number } \\
\text { of plants }\end{array}$ & Confirmation $^{b}$ & $\begin{array}{c}\text { WPBR } \\
\text { severity }^{c}\end{array}$ & $\begin{array}{c}\text { Percentage sites } \\
\text { with infected plants }\end{array}$ & $\begin{array}{c}\text { Number } \\
\text { of sites } \\
\end{array}$ \\
\hline \multirow[t]{6}{*}{ Black currant } & \multirow[t]{5}{*}{ Ribes nigrum } & 'Consort'd & $19 \pm 10$ & 16 & Yes & $19.4 \pm 9.8$ & 29 & 7 \\
\hline & & 'Coronet'd & $60 \pm 25$ & 5 & Yes & $21.1 \pm 10.9$ & 50 & 4 \\
\hline & & 'Crusader'd & $0 \pm 0$ & 8 & No & $0 \pm 0$ & 0 & 3 \\
\hline & & 'Titania'd & $44 \pm 6$ & 72 & Yes & $16 \pm 2.4$ & 38 & 21 \\
\hline & & Willoughby & $38 \pm 18$ & 8 & Yes & $0.6 \pm 0.3$ & 50 & 2 \\
\hline & $R$. odoratum & Crandall & $76 \pm 10$ & 21 & Yes & $0.6 \pm 0.2$ & 86 & 7 \\
\hline Currant $\times$ gooseberry & R. $\times$ nidigrolaria & Josta & $88 \pm 13$ & 8 & Yes & $1.7 \pm 1.3$ & 100 & 1 \\
\hline \multirow[t]{6}{*}{ Gooseberry } & R. oxyacanthoides & Jahns Prairie & $88 \pm 5$ & 43 & Yes & $1.9 \pm 0.5$ & 100 & 15 \\
\hline & \multirow[t]{5}{*}{ R. uva-crispa } & Careless & $67 \pm 33$ & 3 & Yes & $0.2 \pm 0.2$ & 50 & 2 \\
\hline & & Clark & $83 \pm 17$ & 6 & Yes & $0.8 \pm 0.4$ & 100 & 3 \\
\hline & & Crown Bob & $67 \pm 33$ & 3 & Yes & $0.3 \pm 0.1$ & 100 & 1 \\
\hline & & Invicta & $50 \pm 50$ & 2 & No sample & 0.1 & 100 & 1 \\
\hline & & Pixwell & $100 \pm 0$ & 2 & Yes & $0.7 \pm 0.4$ & 100 & 1 \\
\hline \multirow[t]{4}{*}{ Red currant } & \multirow[t]{4}{*}{ R. rubrum } & Jonkheer Van Tets & $24 \pm 8$ & 29 & Yes & $0.1 \pm 0$ & 45 & 11 \\
\hline & & Red Lake & 100 & 1 & Yes & 0.1 & 100 & 1 \\
\hline & & Rolan & $25 \pm 25$ & 4 & No sample & 0.1 & 50 & 2 \\
\hline & & Rondom & $29 \pm 13$ & 14 & No sample & $0.8 \pm 0.3$ & 20 & 5 \\
\hline \multirow[t]{2}{*}{ White currant } & \multirow[t]{2}{*}{ R. rubrum } & 1301 & $0 \pm 0$ & 9 & No & $0 \pm 0$ & 0 & 4 \\
\hline & & Blanka & 100 & 1 & Yes & 1.7 & 100 & 1 \\
\hline
\end{tabular}

\footnotetext{
a Mean disease incidence \pm standard error (SE) for each cultivar. Incidence is defined as percentage of plants with WPBR. A plant (replicate) was considered positive if any of the 18 leaves (subsamples) inspected for severity or other symptomatic leaves had signs of the causal agent of WPBR, Cronartium ribicola.

b Polymerase chain reaction confirmation of $C$. ribicola.

c Mean disease severity of infected plants \pm SE for each cultivar. Disease severity represents the percentage of leaf area with rust pustules produced on the lower side of leaves, including chlorotic halos, necrotic tissue surrounding pustules and coalesced lesions. An estimate was obtained for each plant by calculating the mean percent diseased leaf area for 18 leaves (3 leaves from each of the bottom, middle, and top sections of each of two canes).

d Cr Ribes cultivars.
} 
dominant gene in $R$. nigrum 'Titania' was first reported in 2011 in Connecticut (Frederick et al. 2011).

In this study, we show evidence that the vCr race of $C$. ribicola that has overcome the $\mathrm{Cr}$ resistance dominant gene in cultivated Ribes spp. is present in both cultivated Ribes plants and pine trees in New Hampshire. The now susceptible European black currant cultivars with the $\mathrm{Cr}$ gene ( $\mathrm{Cr}$ Ribes cultivars) pose a threat to neighboring white pine. In the current study, C. ribicola inoculum, collected from New Hampshire infected plants labeled as 'Titania', 'Consort', and 'Coronet', successfully infected leaves of reference accessions of $\mathrm{Cr}$ Ribes cultivars from the Canadian Clonal Genebank. The C. ribicola $\mathrm{vCr}$ race was also found in eastern Canada in surveys conducted during 2013 in commercial black currant fields in Quebec, New Brunswick, Nova Scotia, and Prince Edward Island (Tanguay 2014). In that recent outbreak, Cr Ribes cultivars 'Titania', 'Consort', 'Tisel', and 'Blackcomb' were infected with $C$. ribicola (Tanguay 2014). In the current study, 'Titania' was the most frequently planted (56\% sites) Ribes cultivar in New Hampshire and it was frequently infected by the C. ribicola $\mathrm{vCr}$ race (44\% plants infected). Other $\mathrm{Cr}$ Ribes cultivars surveyed in New Hampshire also exhibited a breakdown in WPBR resistance. In all, 19 and $60 \%$ of 'Consort' and 'Coronet' plants,

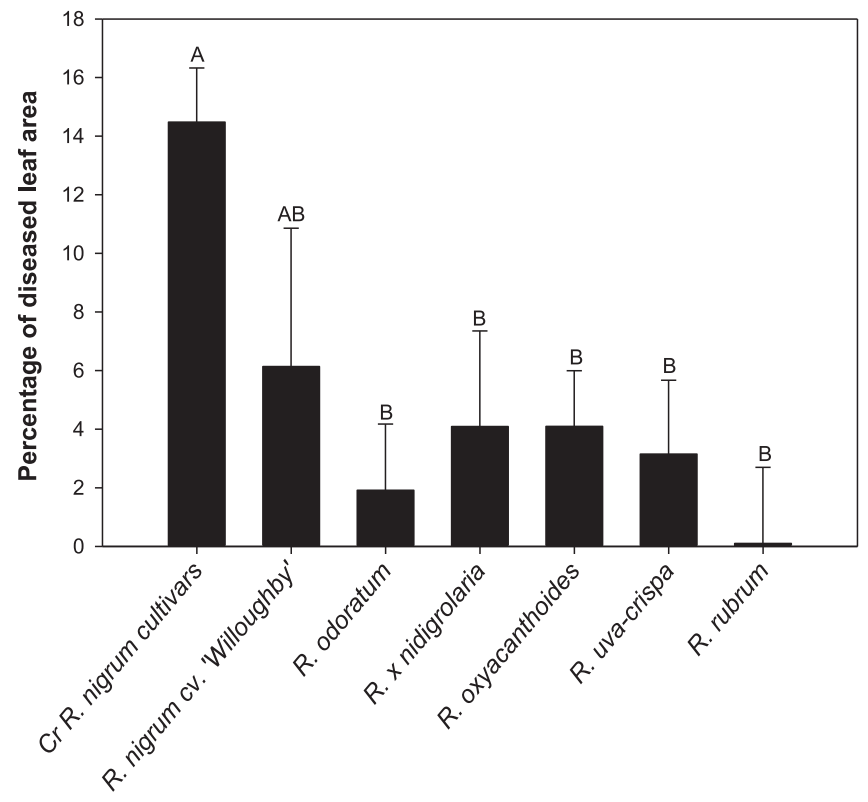

Ribes species

Fig. 3. Comparison of white pine blister rust severity among cultivated Ribes spp. in New Hampshire. European black currant cultivars 'Titania', 'Consort', and 'Coronet' are defined as $\mathrm{Cr}$ Ribes cultivars. Error bars represent standard errors. Values with the same letter are not statistically different $(\alpha=0.05)$. respectively, were infected by $C$. ribicola. Results from the current study suggest that these now susceptible European black currant cultivars pose a threat to local white pine resources, which have greater WPBR incidence in the vicinity of these infected $\mathrm{Cr}$ Ribes plants compared with pine trees growing next to other infected resistant cultivars or uninfected Ribes. The $\mathrm{vCr}$ race of the pathogen also caused cankers in the heavily infected white pine natural forest located close to a 'Titania' planting in eastern Canada (Tanguay et al. 2013). Preliminary genetic analyses confirm that the vCr race of the pathogen that has overcome the $\mathrm{Cr}$ gene in Ribes spp. is the result of a new mutation or the genetic recombination of a North American strain of the fungus and not a new introduction of the disease (Tanguay et al. 2013).

In the Northeast, $R$. nigrum was the most important source of inoculum for the spread of WPBR because this extremely susceptible species grew on abandoned farms close to eastern white pine trees (Maloy 1997; Zambino 2010). European black currant is able to produce greater quantities of more vigorous inoculum compared with other Ribes spp. (Mielke 1943). Plants generally are taller and have large leaves and, consequently, more leaf area is available for inoculum production (Snell 1942; Spaulding 1922b). In addition,

Table 3. Growth of Cronartium ribicola on susceptible control 'Ben Lomond' (without $\mathrm{Cr}$ gene) and reference accessions of black currant cultivars with the $\mathrm{Cr}$ gene (Cr Ribes cultivars) from the Canadian Clonal Genebank inoculated with aeciospores from eastern white pine in New Hampshire growing next to infected Cr Ribes cultivars or negative control inoculum from Canada

\begin{tabular}{|c|c|c|c|c|c|}
\hline \multirow[b]{2}{*}{ Source $^{b}$} & \multirow[b]{2}{*}{$\begin{array}{l}\text { Eastern white } \\
\text { pine tree }\end{array}$} & \multirow[b]{2}{*}{ Canker } & \multirow[b]{2}{*}{$\begin{array}{l}\text { Sampled } \\
\qquad(n)^{c}\end{array}$} & \multicolumn{2}{|c|}{$\begin{array}{l}\text { Number of aecia } \\
\text { with infectious } \\
\text { aeciospores on }\end{array}$} \\
\hline & & & & $\begin{array}{c}\text { Susceptible } \\
\text { Ribes }\end{array}$ & Cr Ribes \\
\hline \multirow[t]{5}{*}{ Epsom } & 1 & 1 & 5 & 4 & 4 \\
\hline & 2 & 1 & 10 & 8 & 8 \\
\hline & 3 & 1 & 10 & 9 & 9 \\
\hline & 4 & 1 & 10 & 8 & 9 \\
\hline & 4 & 2 & 4 & 4 & 4 \\
\hline \multirow[t]{4}{*}{ Concord } & 1 & 1 & 1 & 0 & 0 \\
\hline & 1 & 2 & 1 & 1 & 0 \\
\hline & 2 & 1 & 4 & 2 & 2 \\
\hline & 3 & 1 & 5 & 0 & 1 \\
\hline
\end{tabular}

a Ribes leaf samples from susceptible and reference $\mathrm{Cr}$ Ribes cultivars were inoculated in Canada with New Hampshire inoculum within 4 days of rust collection in the field. Growth of the pathogen was assessed 4 weeks postinoculation. In contrast to susceptible Ribes plants, Cr Ribes cultivars 'Consort', 'Coronet', and 'Crusader' were not infected by negative control bulk aeciospores collected in 2008 from cankers in a white pine plantation in Saint-Isidore (Quebec, Canada).

b Source of New Hampshire inoculum.

c Number of aecia sampled. Spores from each aecium were used to inoculate a leaf sample from each Ribes cultivar.

Table 2. Growth of Cronartium ribicola on susceptible black currant control 'Ben Lomond' (without $\mathrm{Cr}$ gene, $\mathrm{Cr}-$ ) and reference accessions of black currant cultivars with the $\mathrm{Cr}$ gene ( $\mathrm{Cr}+, \mathrm{Cr}$ Ribes cultivars) from the Canadian Clonal Genebank inoculated with urediniospores from plants labeled as ' $\mathrm{Titania}$ ' (Cr+) in New Hampshire or negative control inoculum from Canada ${ }^{a}$

\begin{tabular}{|c|c|c|c|c|c|}
\hline Source of inoculum & Inoculum location & $\begin{array}{c}\text { 'Ben Lomond' }(\mathrm{Cr}-) \\
\text { infected }\end{array}$ & $\begin{array}{l}\text { 'Consort' }(\mathrm{Cr}+) \\
\text { infected }\end{array}$ & $\begin{array}{l}\text { 'Coronet' }(\mathrm{Cr}+) \\
\text { infected }\end{array}$ & $\begin{array}{c}\text { 'Crusader' }(\mathrm{Cr}+) \\
\text { infected }\end{array}$ \\
\hline \multirow[t]{6}{*}{ Urediniospores $^{\mathrm{b}}$} & Durham & Yes & Yes & Yes & Yes \\
\hline & Concord & Yes & Yes & Yes & No \\
\hline & Epsom & Yes & Yes & Yes & Yes \\
\hline & Chichester & Yes & Yes & Yes & Yes \\
\hline & Temple & Yes & Yes & Yes & Yes \\
\hline & Hanover & Yes & Yes & Yes & Yes \\
\hline Aeciospores $^{\mathfrak{c}}$ & Saint-Isidore & Yes & No & No & No \\
\hline
\end{tabular}

a Ribes leaf samples from susceptible and reference Cr Ribes cultivars were inoculated in Canada with New Hampshire inoculum within 3 to 15 days of rust collection in the field. Growth of the pathogen was assessed 4 weeks postinoculation.

b Urediniospores from 'Titania' leaves from New Hampshire.

c Aeciospores from pine cankers from Quebec, Canada. 
compared with other Ribes spp., uredia and telia are larger in size and more abundant (Spaulding 1922a), and basidiospores have a greater survival rate after drying and brief exposure to sunlight on $R$. nigrum (Spaulding and Rathbun-Gravatt 1926).

Susceptible Ribes hosts can be infected by aecial or uredinial inoculum sources hundreds of kilometers away and then produce high levels of inoculum that infect less susceptible but locally abundant Ribes spp. (Zambino 2010). The native Ribes spp. of greatest importance to the initial WPBR epidemic in the Northeast were $R$. cynosbati, $R$. rotundifolium, $R$. glandulosum, and $R$. americanum (Zambino 2010). Today, wild and naturalized Ribes spp. are infrequently found in New England and they are typically restricted to stone walls and wet areas (Bergdahl and Teilon 2000; Zambino 2010). For example, in New Hampshire, Ribes plants were found in only 9 of 35 (17\%) Phase 3 forested, long-term Forest Inventory Analyses plots inventoried from 2007 to 2010 by the USFS (Randall Morin, USFS Northern Research Station's Forest Inventory and Analysis, personal communication). In this study, only 2 of 43 sites had wild or naturalized currant ( $R$. hirtellum and $R$. rubrum, respectively). These plants were not vigorous and, although infected by $C$. ribicola, disease severity was small compared with commercial cultivars.

Severity of WPBR in cultivated Ribes spp. varies with host genotype, environmental conditions, and pathogen population (Zambino

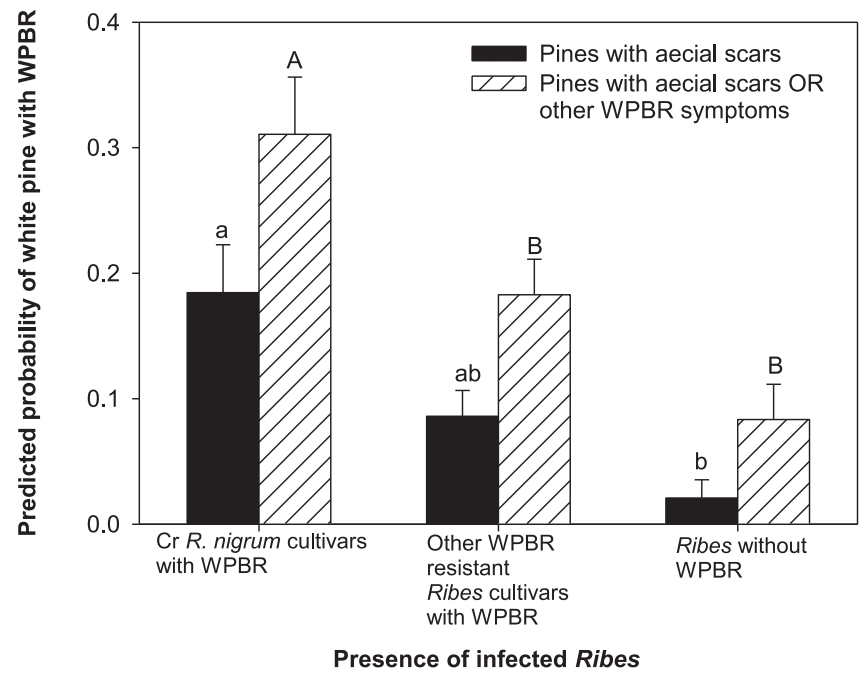

Fig. 4. White pine blister rust (WPBR) incidence of pines in relation to presence of infected Ribes plants in New Hampshire. European black currant cultivars 'Titania', 'Consort', and 'Coronet' are defined as $\mathrm{Cr}$ Ribes cultivars. Values with the same letter are not statistically different $(\alpha=0.05)$.

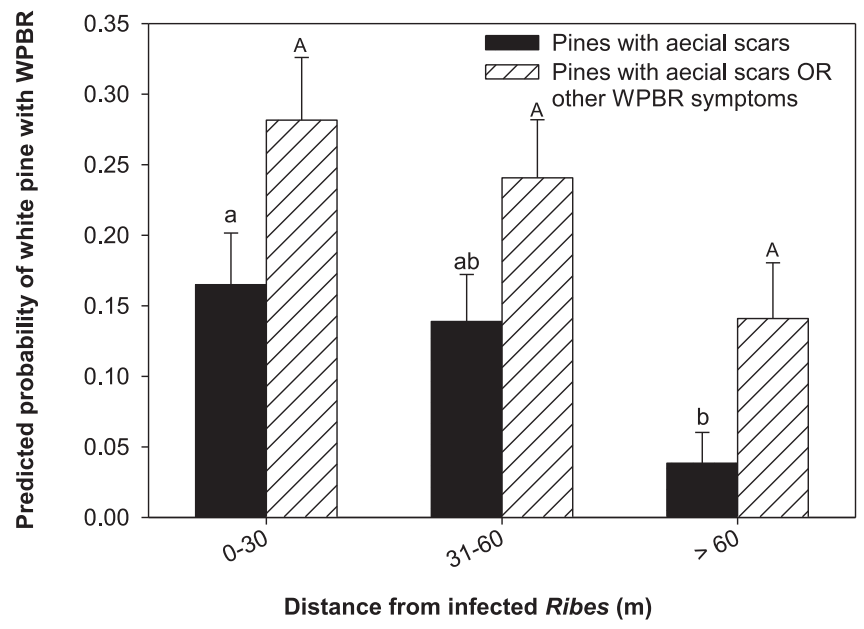

Fig. 5. White pine blister rust (WPBR) incidence of pine in relation to distance from infected Ribes cultivars. Values with the same letter are not statistically different $(\alpha=0.05)$.
2010). For example, red currant ( R. rubrum) 'Rolan' and 'Rondom'; R. uva-crispa 'Captivator', 'Careless', 'Clark', 'Crown Bob', 'Jahns Prairie', and 'Pixell'; and $R$. hirtellum were not infected in Oregon field trials (Hummer 1997). In New Hampshire, all of these Ribes spp. were infected by $C$. ribicola. In this study and in field trials conducted in New York (Snell 1942), disease severity on red currant and gooseberry (R. grossularia) was low. In Finland, red currant 'Jonkheer Van Tets' was highly susceptible to $C$. ribicola (Kaitera and Nuorteva 2006) whereas, in this study, it was not. Differences in environmental conditions among northern Europe and western and eastern North America could explain variation in resistance to WPBR in these Ribes spp. These Ribes spp., however, were also exposed to different strains of C. ribicola. Genetic differentiation among eastern and western populations of C. ribicola is very large and is attributed to a barrier in gene flow due to absence of hosts in the Great Plains (Hamelin et al. 2000). In contrast to results from this study, Cr Ribes 'Consort', 'Coronet', and 'Titania' were not infected by $C$. ribicola under natural field conditions in Oregon (Hummer 1997) or Vermont (Bergdahl and Teilon 2000). The most likely explanation for the lack of disease in 'Consort', 'Coronet', and 'Titania' in Oregon and Vermont is that the C. ribicola $\mathrm{vCr}$ race was not present at the time those field trials were conducted.

Although, in the current study, the presence of $\mathrm{vCr}$ race of $C$. ribicola in New Hampshire was confirmed, it is also possible that some infected black currant plants surveyed in New Hampshire labeled as Cr Ribes cultivars were misidentified. This was the case with 'Consort' accessions purchased at a nursery in Minnesota that became infected by $C$. ribicola but were genetically different from 'Consort' accessions from the USDA-ARS National Clonal Germplasm Repository and the University of Minnesota that were not infected by $C$. ribicola (Burnes et al. 2008). The genetic difference between nursery and reference 'Consort' accessions in that study was attributed to mixing of clones in a nursery or mislabeling. Given the interest in Ribes cultivation and the threat posed by WPBR to the white pine resource, the need to confirm the identity of commercially available Ribes cultivars through molecular markers is justified and deserves further investigation. For example, it would be very useful to develop PCRbased markers for WPBR resistance similar to the marker developed to identify resistance to the black currant gall mite conferred by a single gene (Brennan et al. 2009). The development of such markers would aid in the identification of mislabeled plants and help plant breeders to identify WPBR-resistant varieties.

It is interesting that, under field conditions, Cr Ribes 'Crusader' and white currant ' 1301 ' did not develop WPBR. These plants were relatively rare, growing in three and four of the surveyed locations,

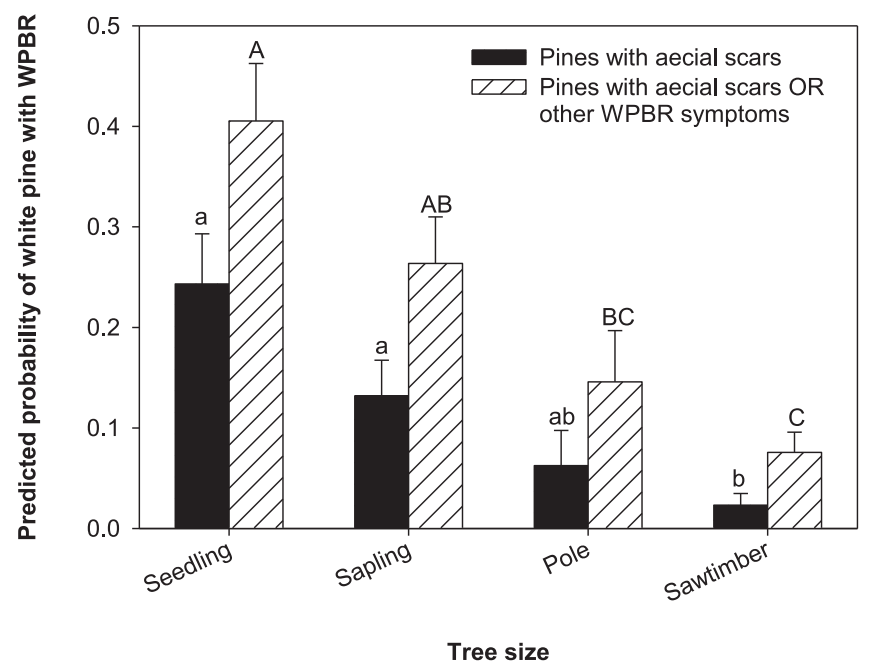

Fig. 6. White pine blister rust (WPBR) incidence of pine in relation to tree size. Pine trees were grouped by stem diameter at breast height (dbh; $1.3 \mathrm{~m}$ above the ground) into seedling (dbh $<2.5 \mathrm{~cm}, n=74)$, sapling (dbh $=2.6$ to $12.6 \mathrm{~cm}$, $n=91$ ), pole (dbh $=12.7$ to $23 \mathrm{~cm}, n=74$ ), and saw timber ( $d b h>23 \mathrm{~cm}, n=$ 172). Values with the same letter are not statistically different $(\alpha=0.05)$. 
respectively. In a couple of these locations, WPBR was absent from white pine and other Ribes spp. were not present, which explains why these cultivars did not have WPBR. In other locations, however, both white pine and other Ribes cultivars had WPBR. In one of these locations, white pine had WPBR but Cr Ribes 'Consort', 'Coronet', and 'Crusader' were disease free, suggesting that the vCr race of the pathogen was absent at this site. In one location for each of the 'Crusader' and '1301' cultivars, both white pine and Cr Ribes cultivars were infected but neither 'Crusader' nor '1301' were infected. Infected Cr Ribes cultivars at these sites could have been mislabeled. Alternatively, 'Crusader' and '1301' plants could be escaping disease through phenology; for example, by leafing out before $C$. ribicola inoculum is available. Finally, it is possible that the white currant '1301' cultivar possesses a gene mechanism alternative to the $\mathrm{Cr}$ dominant gene that is also resistant to the $\mathrm{vCr}$ race. To determine whether '1301' plants are escaping disease or absence of disease in these plants is conferred by resistance genes, it would be necessary to challenge ' 1301 ' plants under controlled experimental conditions with the $\mathrm{vCr}$ race and other C. ribicola strains. If, under controlled inoculations, the '1301' cultivar remained disease-free, it might contain WPBR resistance genes of interest to Ribes breeders and growers. Similarly, it would be important to discern the mechanisms of WPBR resistance or escape of red currant cultivars that exhibited low disease severity in the field in the current study. Indeed, the Ribes gene pool in North America needs to be surveyed for WPBR resistance mechanisms alternative to the $\mathrm{Cr}$ dominant gene for resistance (Hummer and Dale 2010). It would be useful to map these genetic resistance traits with molecular markers, as described by Brennan et al. (2009).

At least $10 \%$ of the eastern white pine trees sampled in this study were infected with WPBR, which is a greater proportion than the $2.4 \%$ incidence previously reported in an extensive statewide survey (Lombard and Bofinger 1999). Other factors previously associated with WPBR such as proximity to susceptible Ribes plants, prevailing wind direction, and tree size were also associated with greater disease incidence in the current study. Incidence of pine infection declines sharply with distance from a source (Posey and Ford 1924; Van Arsdel 1960). In this study, proximity to susceptible black currant also significantly increased the probability of WPBR incidence on white pine. Although weather in New England in highly variable, the prevailing wind direction has a westerly component, whereas southeast winds are least common (Keim 1998). Accordingly, infected pine trees were least likely to occur north of inoculum sources. In this study, seedlings were more frequently infected than larger trees. Seedlings are more exposed to infection by $C$. ribicola compared with large trees because they have needles closer to the ground, where more spores from Ribes and favorable conditions for infection occur (Lachmund 1933; Mielke 1943).

For more than seven decades, Federal and State agencies have cooperated to remove Ribes spp. from selected white pine stands (Maloy 1997). Some stands were worked over up to five times (Benedict 1981). In the production regions with eastern white pine, $\$ 38,632,855$ was spent on Ribes eradication efforts by 1959 (Benedict 1981). Ribes eradication successfully controlled and reduced WPBR in northeastern states (Lombard and Bofinger 1999; Martin 1944; Ostrofsky et al. 1988; Van Arsdel 1960). A 50\% reduction in WPBR incidence on white pine was observed in Maine after 70 years of Ribes eradication (Ostrofsky et al. 1988). In Maine, WPBR caused $50 \%$ of the white pine mortality in untreated areas versus $14 \%$ mortality in treated areas. Incidence of WPBR on pine was almost three times greater in untreated areas $(9 \%)$ than in treated areas $(3.8 \%)$ (Ostrofsky et al. 1988). In New Hampshire, only $2.4 \%$ of white pine trees sampled in an extensive statewide survey were infected by C. ribicola (Lombard and Bofinger 1999).

Results from the current study show that disease incidence is greater in eastern white pine in the proximity of $\mathrm{Cr}$ Ribes cultivars overcome by the $C$. ribicola $\mathrm{vCr}$ race. In addition, WPBR incidence and severity were evaluated for 15 WPBR-resistant Ribes cultivars under field conditions. This information is useful to states that want consistent data with which to make decisions about plant regulations (McKay 2000). As a result of this investigation, Cr Ribes cultivars have been removed from the list of approved Ribes cultivars for planting in New Hampshire.

\section{Acknowledgments}

This study was funded by USDA Forest Service Evaluation Monitoring grant NE-EM-B-13-01. We thank K. Lombard, P. Siegert, C. Smith, and K. Gooch for their contribution in the development of this study; D. Schneider for processing samples in 2012; K. Hummer and P. Zambino for providing advice and helpful suggestions; J. Stanovick for being instrumental in developing the study design and statistical analyses; A. Potvin for help with rust inoculations under controlled conditions; E. Jordan for assistance with fieldwork; T. Rawisnki for identifying wild Ribes spp.; J. Bubar and permit holders who allowed access to their properties; and the editor and two anonymous reviewers for their comments and suggestions.

\section{Literature Cited}

Angelotti, F., Scapin, C. R., Tessmann, D. J., Vida, J. B., Oliveira, R. R., and Canteri, M. G. 2008. Diagrammatic scale for assessment of grapevine rust. Trop. Plant Pathol. 33:439-443.

Aukema, J. E., McCullough, D. G., Holle, B. V., Liebhold, A. M., Britton, K., and Frankel, S. J. 2010. Historical accumulation of nonindigenous forest pests in the continental United States. Bioscience 60:886-897.

Benedict, W. V. 1981. History of white pine blister rust control-A personal account. U.S. Dep. Agric. For. Serv. Rep. FS-355. Washington, DC.

Bergdahl, D. R., and Teilon, H. 2000. White pine blister rust in Vermont: Past, present, and concerns for the future. Horttechnology 10:537-541.

Brar, S. 2012. Landscape genetics of Cronartium ribicola. Master's dissertation, The University of British Columbia. Online publication. https://circle.ubc. ca/handle/2429/43138

Brennan, R., Jorgensen, L., Gordon, S., Loades, K., Hackett, C., and Russell, J. 2009. The development of a PCR-based marker linked to resistance to the blackcurrant gall mite (Cecidophyopsis ribis Acari: Eriophyidae). Theor. Appl. Genet. 118:205-211.

Burnes, T. A., Blanchette, R. A., Smith, J. A., and Luby, J. J. 2008. Black curran clonal identity and white pine blister rust resistance. HortScience 43:200-202.

Cox, K. D., Jordan, R. A., Reisch, M. J., and McCarthy, M. L. 2008. Evaluating biopesticides for managing white pine blister rust of currant, 2007. Plant Dis. Manag. Rep. 2:SMF033.

Dalton, D. T., Postman, J. D., and Hummer, K. E. 2010. Comparative infectivity of Cronartium ribicola aeciospores and urediniospores in genotypes of Ribes nigrum. Plant Dis. 94:461-464.

Frederick, Z. A., Los, L., Allen, J., and Cox, K. 2011. First report of white pine blister rust caused by Cronartium ribicola on immune black currant Ribes nigrum cv. Titania in Preston, Connecticut. Plant Dis. 95:1589.

Gardes, M., and Bruns, T. D. 1993. ITS primers with enhanced specificity for basidiomycetes-application to identification of mycorrhizae and rusts. Mol. Ecol. 2:113-118.

Geils, B. W., Hummer, K. E., and Hunt, R. S. 2010. White pines, Ribes, and blister rust: A review and synthesis. For. Pathol. 40:147-185.

Hamelin, R. C., Hunt, R. S., Geils, B. W., Jensen, G. D., Jacobi, V., and Lecours, N. 2000. Barrier to gene flow between eastern and western populations of Cronartium ribicola in North America. Phytopathology 90:1073-1078.

Hummer, K. E. 1997. Diamonds in the rust: Ribes resistance to white pine blister rust. Fruit Var. J. 51:112-117.

Hummer, K. E., and Dale, A. 2010. Horticulture of Ribes. For. Pathol. 40:251-263.

Hummer, K. E., and Finn, C. 1999. Three-year update on Ribes susceptibility to white pine blister rust. Acta Hortic. 505:403-408.

Hummer, K. E., and Picton, D. D. 2002. Pine blister rust resistance screening in Ribes germplasm. Acta Hortic. 585:287-291.

Kaitera, J., and Nuorteva, H. 2006. Susceptibility of Ribes spp. to pine stem rusts in Finland. For. Pathol. 36:225-246.

Kasanen, R. 1997. Aeciospores of Cronartium flaccidum, C. ribicola and Endocronartium pini show no differences in morphology. Eur. J. Forest Pathol. 27:251-260.

Kearns, H. S. J., and Jacobi, W. R. 2007. The distribution and incidence of white pine blister rust in central and southeastern Wyoming and northern Colorado. Can. J. For. Res. 37:462-472.

Keim, B. 1998. A climate primer for New England. Chapter 2, Pages 10-12 in: New England's Changing Climate, Weather, and Air Quality. Climate Change Research Center, Institute for the Study of Earth, Oceans, and Space, Durham, $\mathrm{NH}$.

Lachmund, H. G. 1933. Mode of entrance and periods in the life cycle of Cronartium ribicola on Pinus monticola. J. Agric. Res. 47:791-805.

Liebhold, A. M., Brockerhoff, E. G., Garrett, L. J., Parke, J. L., and Britton, K. O. 2012. Live plant imports: The major pathway for forest insect and pathogen invasions of the US. Front. Ecol. Environ 10:135-143.

Liebhold, A. M., Macdonald, W. L., Bergdahl, D., and Maestro, V. C. 1995 Invasion by exotic forest pests-A threat to forest ecosystems. For. Sci. 41:1-49.

Lombard, K., and Bofinger, J. 1999. White pine blister rust, Cronartium ribicola, infestation incidence for selected areas of New Hampshire. Online publication. New Hampshire Department of Resources and Economic Development, Division of Forests and Lands, Durham, NH. http://extension.unh.edu/resources/files/ resource000413_rep435.pdf 
Luffman, M. 2000. Canadian breeding program for white pine blister resistance in black currants. Horttechnology 10:555-556.

Maloy, O. C. 1997. White pine blister rust control in North America: A case history. Annu. Rev. Phytopathol. 35:87-109.

Martin, J. F. 1937. Protect White Pine from Blister Rust. U.S. Department of Agriculture, Bureau of Entomology and Plant Quarantine, Washington, D.C.

Martin, J. F. 1944. Ribes eradication effectively controls white pine blister rust. J. For. 42:255-260.

McKay, S. 2000. State regulation of Ribes to control white pine blister rust. Horttechnology 10:562-564.

Mielke, J. L. 1943. White pine blister rust in western North America. Yale Univ. School For. Bull. 52. New Haven, CT.

North East State Foresters Association (NESFA). 2013. The economic importance of the forest-based economies of Maine, New Hampshire, New York, and Vermont, 2013. North East State Foresters Association, Concord, NH. http://www.nefainfo. org/publications.html

Ostrofsky, W. D., Rumpf, T., Struble, D., and Bradbury, R. 1988. Incidence of white pine blister rust in Maine after 70 years of Ribes eradication program. Plant Dis. 72:967-970.

Ostry, M. E., Laflamme, G., and Katovich, S. A. 2010. Silvicultural approaches for management of eastern white pine to minimize impacts of damaging agents. For. Pathol. 40:332-346.

Pedersen, H. L. 1998. Field resistance of black currant cultivars (Ribes nigrum L.) to diseases and pests. Fruit Var. J. 52:6-10.

Pedersen, H. L. 2008. Juice quality and yield capacity of black currant cultivars in Denmark. Acta Hortic. (ISHS) 777:510-516.

Posey, G. B., and Ford, E. R. 1924. Survey of blister rust infection on pines at Kittery Point, Maine, and the effect of Ribes eradication in controlling the disease. J. Agric. Res. 28:1253-1258.

Slipp, A. W. 1953. Survival probability and its application to damage survey in western white pine infected with blister rust. Idaho Univ. For. Range Wildlife Exp. Stn. Res. Note 7. Moscow, ID.

Smith, J. A., Blanchette, R. A., Burnes, T. A., Jacobs, J. J., Higgins, L., Witthuhn, B. A., David, A. J., and Gillman, J. H. 2006. Proteomic comparison of needles from blister rust-resistant and susceptible Pinus strobus seedlings reveals upregulation of putative disease resistant proteins. Mol. Plant-Microbe Interact. 19:150-160.

Snell, W. H. 1942. The production of sporidia of Cronartium ribicola on cultivated red currants in relation to infection of white pine. Am. J. Bot. 29:506-513.

Spaulding, P. 1911. The blister rust of white pine. Bur. Plant Ind. Bull. 206. Washington, DC., 88 pp.

Spaulding, P. 1922b. Viability of telia of Cronartium ribicola in early winter Phytopathology 12:221-224.

Spaulding, P. 1922a. Investigations of the white-pine blister rust. U.S. Dep. Agric. For. Serv. Bull. 957. Washington, DC

Spaulding, P., and Rathbun-Gravatt, A. 1926. The influence of physical factors on the viability of sporidia of Cronartium ribicola. J. Agric. Res. 33: 397-433.

Stewart, F. C. 1906. An outbreak of European currant rust (Cronartium ribicola Dietr.). N. Y. Agric. Exp. Stn. Tech. Bull. 2:61-73. Geneva, NY.

Tanguay, P. 2014. Distribution in Canada of a new Cronartium ribicola race virulent on previously immune black currant cultivars. (Abstr.) Phytopathology 104:S1.6.

Tanguay, P., Bergeron, M. J., Tsui, C., Brar, S., Lamarche, J., and Hamelin, R. C. 2013. The origin of a new race of Cronartium ribicola, virulent on previously immune blackcurrant cultivars, and rapidly spreading in eastern North America. (Abstr.) Phytopathology 103:S2.143.

Van Arsdel, E. P. 1960. Infection decline rates in alternate host eradication rust control. (Abstr.) Phytopathology 70:572.

Widmann, R., and McWilliams, W. 2003. An overview of the white pine resource in New England using forest inventory and analyses data. Pages 1-8 in: Managing White Pine in a New Millennium. K. Bennett and K. Desmarais, eds. University of New Hampshire Cooperative Extension, Hillsborough.

Yamasaki, M. 2003. White pine as wildlife habitat. Pages 33-36 in: Managing White Pine in a New Millennium. K. Benett and K. Desmarai, eds. University of New Hampshire Cooperative Extension, Hillsborough.

Zambino, P. J. 2010. Biology and pathology of Ribes and their implications for management of white pine blister rust. For. Pathol. 40:264-291. 